\section{Induction of Parthenogenetic Haploid Embryos after Pollination by Irradiated Pollen in Watermelon}

\author{
N. Sari and K. Abak \\ Cukurova University, Faculty of Agriculture, Department of Horticulture, \\ Adana, Turkey \\ M. Pitrat, J.C. Rode, and R. Dumas de Vaulx \\ Station d'Amélioration des Plantes Maraîchères, Institut National de la \\ Recherche Agronomique, BP 94, 84143 Montfavet cedex, France
}

Additional index words. Citrullus lanatus, in vitro culture, flow cytometry

\begin{abstract}
Parthenogenetic haploid embryos of 'Crimson Sweet', 'Halep Karasi', 'Sugar Baby' and 'Panonia $F_{1}$ ' watermelon [Citrullus lanatus (Thunb.) Matsum. \& Nakai] were obtained after pollination with $\gamma$-irradiated ( 200 or $300 \mathrm{~Gy}$ ) pollen. Some globular and heart-shaped embryos were observed in fruit harvested 2 to 5 weeks after pollination. The number of embryos per 100 seeds was highest for 'Halep Karasi'. After in vitro culture, 17 haploid plants were obtained and doubled haploid lines were generated after chromosome doubling using colchicine.
\end{abstract}

Swaminathan and Singh (1958) reported the first haploid $(n=11)$ watermelon plant with one haploid branch on a plant derived from seed treated with X-rays. Xue et al. (1983) used anther culture to obtain haploid plants, but these plants failed to develop after transplanting. In the Cucurbitaceae, parthenogenetic haploid melon (Cucumis melo L.) (Sari et al., 1992a; Sauton, 1988) and cucumber (Cucumis sativus L.) (Niemirowicz-Szczytt and Dumas de Vaulx, 1989; Truong-Andre, 1988) plants were obtained after pollination with $\gamma$-irradiated pollen. We used the same method to obtain haploid plants that then were doubled; these plants can be used in watermelon breeding programs.

\section{Material and Methods}

The watermelons used were an $F_{1}$ hybrid ('Panonia') and the open-pollinated lines 'Crimson Sweet', 'Halep Karasi', and 'Sugar Baby'. At 15-day intervals, starting from the first week of January, we made seven sowings to investigate the effect of season on haploid embryo production. Seeds were sown in 0.5 liter pots filled with a steam-disinfected mixture of 1 peatmoss : 4 potting soil $(\mathrm{v} / \mathrm{v})$. Pots were placed on a germinating table that kept the soil at $25 \mathrm{C}$ in a greenhouse. Seedlings were transplanted in natural soil in a greenhouse or under plastic tunnels. Double row spacing was used at 50 to $100 \mathrm{~cm}$, and plants had a $50-\mathrm{cm}$ in-row spacing.

The day before anthesis, male flowers were collected, and their petals and sepals were

Received for publication 1 June 1993. Accepted for publication 14 Mar. 1994. The cost of publishing this paper was defrayed in part by the payment of page charges. Under postal regulations, this paper therefore must be hereby marked advertisement solely to indicate this fact. removed partially. The prepared buds were put into glass tubes closed with cotton and placed in a reactor that supplied $\gamma$ rays from $\mathrm{Co}^{60}$ at $0.85 \mathrm{~Gy} \cdot \mathrm{min}^{-1}$. A 300-Gy dose was selected based on Sauton and Dumas de Vaulx's (1987) results on melon. In some experiments, we used a 200-Gy dose. When possible, fresh pollen was used because irradiated-pollen germination decreased rapidly (Sari et al., 1992b). In some cases, we used pollen extracted in n-pentane and stored at 4C (Risser and Rode, 1984). The day before anthesis, hermaphroditic flowers of the andromonoecious 'Halep Karasi' were emasculated and enclosed in cellophane bags to avoid uncontrolled pollination by bees; the other cultivars are monoecious. The following day, pollinations were made with the irradiated male flowers (at least three to four male flowers were used per female flower), and the female flowers were covered with cellophane bags for 3 to 5 days. Fruit were harvested 2 to 5 weeks after pollination and surface disinfected with $95 \%$ alcohol. Seeds were opened individually under a stereomicroscope in a laminar flow hood. Embryos were initially cultured in petri dishes ( $5 \mathrm{~cm}$ in diameter) on the basic E20A medium (Sauton and Dumas de Vaulx, 1987) supplemented with $0.57 \mu \mathrm{M}$ indole-3-acetic acid, transferred to the same medium in $22 \times 2-\mathrm{cm}$ tubes, and incubated in climatic chambers at $26 \mathrm{C}$ and 12-h photoperiod (16 to $19 \mu \mathrm{mol} \cdot \mathrm{m}^{-2} \cdot \mathrm{s}^{-1}$, supplied by cool-white fluorescent tubes).

Flow cytometry was performed at the Institut Montpelliérain d'Imagerie Médicobiologique, Montpellier, France, using a cytometer (model ACR 1400; Bruker, Montpellier, France) equipped with a mercury vapor lamp (USHIO-102DH-100W) and four photomultiplier tubes (excitation wavelength $=490 \pm 10 \mathrm{~nm}$, propidium iodide fluorescence $=640 \pm 80 \mathrm{~nm}$ ). The putative haploid plantlets were micropropagated in vitro, and mi- croshoots were transplanted to pots in the greenhouse. Leaf tissues collected from microshoots and transplanted cuttings were analyzed for cytometry. Leaf tissues were dilacerated with a razor blade in $0.5 \mathrm{ml}$ of phosphate buffer ( $\mathrm{pH} 7.1$ ) with (in $\mathrm{mm}$ ) 20 $\mathrm{KNO}_{3}, 20 \mathrm{NH}_{4} \mathrm{NO}_{3}, 3 \mathrm{CaCl}_{2}, 1.5 \mathrm{MgSO}_{4}, 1.2$ $\mathrm{KH}_{2} \mathrm{PO}_{4}, 50$ sorbitol, and $50 \mathrm{Na}$-thioglycolate. The suspension was filtered through a $50-\mu \mathrm{m}$ nylon mesh. Propidium iodide $(75 \mu \mathrm{m})$ and Triton X-100 (0.1\%, v/v) were added, and the sample was placed in darkness at $4 \mathrm{C}$ for 15 min before analysis. Our technique was based on the measurement of DNA stained with fluorochrome and the color intensity related with the cell DNA.

Haploid plants were propagated in vitro by cuttings placed on E20A medium, and chromosome doubling was performed with a 5- to 10 -g.liter ${ }^{-1}$ aqueous colchicine solution for 1 , 2,4 , or $6 \mathrm{~h}$.

\section{Results}

For the first sowings, the temperatures were too low (even under heated glasshouses) to obtain a good fruit set; Sauton (1988) reported similar problems for melon. A good fruit set with many seeds per fruit was obtained only for pollinations made after 16 May (Table 1). In $5.5 \%$ of the seeds that contained embryos, $72.8 \%$ had globular stage embryos, and $0.7 \%$ had well-formed, heart-shaped embryos. Of the remaining seeds (26.5\%), $17.1 \%$ were necrotic, and $9.2 \%$ were soft, heartshaped embryos.

There were significant differences in the number of seeds that produced embryos among the four cultivars tested (Table 1). 'Halep Karasi' had the highest number of embryos per 100 seeds; however, in this cultivar, white, heart-shaped embryos were absent. Germination of various embryo types was difficult. There were no significant differences between cultivars in the number of plants obtained per 100 embryos or per 1000 seeds. There were only 0.6 to 1.3 plants that grew per fruit from the seed that had been obtained, regardless of cultivar.

The influence of the time between pollination and in vitro culture of the embryos also was studied. The highest number of plants per 100 embryos was obtained 2 to 4 weeks after pollination (Table 2). At 5 weeks, the number of embryos per 100 seeds was significantly higher than at 3 or 4 weeks, but the number of plants per 100 embryos was low.

A diploid cell contains a 2C DNA level in G0/G1 and 4C in G2 as determined by flow cytometry. The diploid control ('Sugar Baby') exhibited no cells with $1 \mathrm{C}, 27 \%$ at the $2 \mathrm{C}$, and $47 \%$ at the $4 \mathrm{C}$ level (Table 3 ). In contrast, the plants obtained after pollination with irradiated pollen showed $45 \%$ to $71 \%$ of leaf cells at the $1 \mathrm{C}, 23 \%$ to $31 \%$ at the $2 \mathrm{C}$, and $3 \%$ to $6 \%$ at the $4 \mathrm{C}$ level. There were no clear differences between the cuttings of leaves taken from in vitro- or greenhouse-grown plants. Compared with the respective diploid cultivars, these plants were less vigorous and had smaller leaves and flowers with a few empty pollen 
Propagation \& Tissue Culture

Table 1. Embryo types and number of plants obtained after pollination of four watermelon cultivars by $\gamma$-irradiated ( 300 Gy) pollen between 16 May and 13 June.

\begin{tabular}{lccccccrcccc}
\hline \hline Cultivar & $\begin{array}{c}\text { No. } \\
\text { fruit }\end{array}$ & $\begin{array}{c}\text { No. } \\
\text { seed }\end{array}$ & $\begin{array}{c}\text { No. } \\
\text { embryos }\end{array}$ & $\begin{array}{c}\text { No. embryos/ } \\
100 \text { seeds }\end{array}$ & $\begin{array}{c}\text { HSE }^{z} \\
(\%)\end{array}$ & $\begin{array}{c}\text { Necrotic } \\
\text { HSE }^{z}(\%)\end{array}$ & $\begin{array}{c}\text { Soft } \\
\text { HSE }^{z}(\%)\end{array}$ & $\begin{array}{c}\text { Globular } \\
\text { embryos }\end{array}$ & $\begin{array}{c}\text { No. plants } \\
\text { obtained }\end{array}$ & $\begin{array}{c}\text { No. plants/ } \\
100 \text { embryos }\end{array}$ & $\begin{array}{c}\text { No. plants/ } \\
1000 \text { seeds }\end{array}$ \\
\hline Crimson Sweet & 6 & 1,784 & 71 & $4.0 \mathrm{~b}^{y}$ & 1.4 & 26.8 & 4.2 & 68 & 1 & $1.4 \mathrm{a}^{\mathrm{y}}$ & $0.6 \mathrm{a}^{y}$ \\
Halep Karasi & 4 & 1,616 & 229 & $14.2 \mathrm{a}$ & 0 & 22.3 & 13.5 & 64 & 5 & $2.2 \mathrm{a}$ & $3.1 \mathrm{a}$ \\
Panonia & 7 & 4,222 & 170 & $4.0 \mathrm{~b}$ & 2.4 & 14.1 & 4.1 & 79 & 6 & $3.5 \mathrm{a}$ & $1.4 \mathrm{a}$ \\
Sugar Baby & 9 & 6,222 & 291 & $4.7 \mathrm{~b}$ & 0 & 12.5 & 10.0 & 77 & 5 & $1.7 \mathrm{a}$ & $0.8 \mathrm{a}$ \\
Total & 26 & 13,844 & 761 & 5.5 & 0.7 & 17.1 & 9.2 & 73 & 17 & 2.2 & 1.2 \\
\hline
\end{tabular}

${ }^{\mathrm{z}} \mathrm{HSE}=$ heart-shaped embryo.

${ }^{\mathrm{y}}$ Mean separation in columns at $\mathrm{P} \leq 0.05$ (comparison of the proportions by the hypergeometric law).

Table 2. Type of embryos and number of plants obtained 2 to 5 weeks after pollination of four watermelon cultivars by $\gamma$-irradiated pollen.

\begin{tabular}{|c|c|c|c|c|c|c|c|c|c|c|c|}
\hline $\begin{array}{l}\text { Weeks after } \\
\text { pollination }\end{array}$ & $\begin{array}{l}\text { No. } \\
\text { fruit }\end{array}$ & $\begin{array}{l}\text { No. } \\
\text { seed }\end{array}$ & $\begin{array}{c}\text { No. } \\
\text { embryos }\end{array}$ & $\begin{array}{c}\text { No. embryos/ } \\
100 \text { seeds }\end{array}$ & $\begin{array}{l}\mathrm{HSE}^{\mathrm{z}} \\
(\%)\end{array}$ & $\begin{array}{l}\text { Necrotic } \\
\operatorname{HSE}^{z}(\%)\end{array}$ & $\begin{array}{c}\text { Soft } \\
\operatorname{HSE}^{z}(\%)\end{array}$ & $\begin{array}{l}\text { Globular } \\
\text { embryos }\end{array}$ & $\begin{array}{c}\text { No. plants } \\
\text { obtained }\end{array}$ & $\begin{array}{c}\text { No. plants/ } \\
100 \text { embryos }\end{array}$ & $\begin{array}{l}\text { No. plants/ } \\
1000 \text { seeds }\end{array}$ \\
\hline 2 & 5 & 2336 & 166 & $7.1 \mathrm{a}^{\mathrm{y}}$ & 0 & 26.5 & 12.7 & 61 & 4 & $2.4 \mathrm{ab}^{\mathrm{y}}$ & 1.7 \\
\hline 3 & 5 & 2695 & 148 & $5.5 \mathrm{~b}$ & 1.4 & 8.8 & 4.7 & 85 & 5 & $3.4 \mathrm{a}$ & 1.8 \\
\hline 4 & 13 & 6281 & 235 & $3.7 \mathrm{c}$ & 1.3 & 20.0 & 3.8 & 75 & 7 & $3.0 \mathrm{a}$ & 1.1 \\
\hline 5 & 3 & 2532 & 210 & $8.3 \mathrm{a}$ & 0 & 12.4 & 15.7 & 72 & 1 & $0.5 \mathrm{~b}$ & 0.4 \\
\hline
\end{tabular}

${ }^{\mathrm{z}} \mathrm{HSE}=$ heart-shaped embryo.

${ }^{\mathrm{y}}$ Mean separation in columns at $P \leq 0.05$ (comparison of the proportions by the hypergeometric law).

grains. Hence, we concluded that the plants were haploids.

Chromosome doubling of these haploid plants to obtain homozygous diploid genotypes was performed by treating the in vitro cuttings with $1 \%$ colchicine for 2 to $4 \mathrm{~h}$. We attempted the method for melon $(0.5 \%$ colchicine for 2-h treatment on in vitro cuttings), but we were unsuccessful, suggesting that watermelon is less sensitive to colchicine. Diploid (doubled haploid) plants with normal leaf size, vigor, and fertility have been obtained and selfed so that progenies can be studied.

Pollination by $\gamma$-irradiated pollen can induce haploid embryo development in watermelon. In watermelon, haploid embryo yield (measured by the number of haploid plants per fruit or per 1000 seeds) is still low and must be improved before this method can be used routinely in breeding programs.

\section{Literature Cited}

Niemirowicz-Szczytt, K. and R. Dumas de Vaulx. 1989. Preliminary data on haploid cucumber (Cucumis sativus L.) induction. Cucurbit Genet. Coop. Rpt. 12:24-25.

Risser, G. and J.C. Rode. 1984. Use of n-pentane for mixing melon pollen. Cucurbit Genet. Coop. Rpt. 7:54.

Table 3. Frequency of leaf cells with various DNA components (ploidy level) in regenerated watermelon plants.

\begin{tabular}{lcccccr}
\hline \hline Cultivar & Conditions $^{\mathrm{z}}$ & $1 \mathrm{C}^{\mathrm{y}}$ & $2 \mathrm{C}^{\mathrm{y}}$ & $4 \mathrm{C}^{\mathrm{y}}$ & $8 \mathrm{C}^{\mathrm{y}}$ & No. cells \\
\hline Crimson Sweet & $\mathrm{A}$ & 70.7 & 23.3 & 2.9 & 0.6 & 6,072 \\
& $\mathrm{~B}$ & 49.2 & 28.7 & 4.6 & 2.0 & 3,552 \\
Halep Karasi & $\mathrm{A}$ & 52.9 & 26.3 & 6.3 & 3.3 & 5,721 \\
& $\mathrm{~B}$ & 49.3 & 28.5 & 4.9 & 1.5 & 3,202 \\
Sugar Baby & $\mathrm{A}$ & 44.6 & 31.2 & 6.2 & 3.6 & 5,908 \\
& $\mathrm{~B}$ & 50.2 & 28.5 & 4.0 & 1.3 & 5,670 \\
& $\mathrm{C}$ & 0.00 & 26.6 & 47.1 & 3.1 & 28,873 \\
\hline
\end{tabular}

${ }^{{ }^{2} \mathrm{~A}}=$ cuttings transplanted in pots in the greenhouse; $\mathrm{B}=$ in vitro cuttings; $\mathrm{C}=$ plants from seeds in the greenhouse (diploid control).

'Percentage of cells with $1 \mathrm{C}, 2 \mathrm{C}, 4 \mathrm{C}$, and $8 \mathrm{C}$ DNA. The total is not $100 \%$ because there is an internal control in each sample.

Sari, N., K. Abak, M. Pitrat, and R. Dumas de Vaulx. 1992a. Induction of parthenogenetic haploid embryos and plant obtention in melon (Cucumis melo L. var. inodorus Naud ve C. melo L. var. reticulatus Naud). Turkish J. Agr. Forestry $16: 302-314$

Sari, N., K. Abak, M. Pitrat, J.C. Rode, and R. Dumas de Vaulx. 1992b. Haploid plant obtention in watermelon (Citrullus lanatus (Thunb.) Mansf.): Change in germination ability of pollens after irradiation. Kukem Dergisi 15(2):15-21.

Sauton, A. 1988. Effect of season and genotype on gynogenetic haploid production in muskmelon (Cucumis melo L.). Scientia Hort. 35:71-75.
Sauton, A. and R. Dumas de Vaulx. 1987. Obtention de plantes haploides chez le melon (Cucumis melo L.) par gynogénèse induite par du pollen irradié. Agronomie 7(2):141-148.

Swaminathan, M.S. and M.P. Singh. 1958. X-ray induced somatic haploidy in watermelon. Curr. Sci. 27:63-64.

Truong-Andre, I. 1988. In vitro haploid plants derived from pollination by irradiated pollen on cucumber. Proc. EUCARPIA Meeting on $\mathrm{Cu}$ curbit Genetics and Breeding, Avignon, France, 31 May-2 June 1988.

Xue, G.R., W.Y. Yu, and K.W. Fei. 1983. Watermelon plants derived by in vitro anther culture. Plant Physiol. Commun. 4:40-42. 